This is not the version of record. The final version of Umar, Tariq (2018) Causes of delay in construction projects in Oman. Middle East Journal of Management, 5(2), pp. 121-136. can be found at: https://doi.org/10.1504/MEJM.2018.091132 


\title{
Causes of delay in Construction Projects in Oman
}

\begin{abstract}
Construction is a major industry providing jobs to millions of people and contributing to the country's and the world economy. Contribution towards the Omani economy is around $10 \%$ of the total GDP and employs $18 \%$ of the total population. Construction projects are full of risk and uncertainties and delays can have negative economic consequences and can create bad image for all the parties involved in the project. Delays in construction projects have several causes associated with owner, consultant and contractors. This paper aims to explore the causes of delays in construction projects in Oman. The causes of delays in construction projects are firstly discussed with a review of different published literature. The results of interviews with experienced construction professional working with client, consultant and contractor are reported. Results reveal that contractual issues, workforce, materials, coordination between construction parties, and external factors are the main factors which cause delay to construction projects in Oman. The view of different interviewees were however not similar on some of the factors which causes the delay to construction projects. Owner, consultant and contractor are the important team players in successful completion of construction project. Any delay causing factor identified by one team player is important even if it is not considered as important by other party. This research work is exploratory in nature and provides basic causes of delays in construction project in general. Further research is recommended to explore project's specific causes of delay in construction in Oman.
\end{abstract}

Key Words: Management, Project management, Contracting, Planning \& scheduling, Construction Projects, Qualitative Method, Causes of Delay. 


\section{Introduction}

Construction is a major industry providing jobs to millions of people and contributing to the country's and the world economy. Contribution towards the Omani economy is around $10 \%$ of the total GDP and employs $18 \%$ of the total population (NCSI 2015). The ongoing and planned construction projects in Oman for financial year 2015-2016 amount to a total value of US \$ 43.160 Billion. The values of ongoing and planned projects, in different sectors of Oman are shown in figure 1. This includes the largest project " Oman Rail", which is in pre-execution phase with a total length of 2,135 kilometers and a budget of US $\$ 15.6$ billion. $43 \%$ of the total population of Oman consists of foreigners and up to $83 \%$ of the total population of foreigners is employed by the private sector (GLMM 2015). The construction industry is rapidly growing and has huge potential for employment for Omani nationals, which is currently at $8 \%$ only. The construction industry in Oman is highly populated by foreign workers and employs up to $37 \%$ $(644,000)$ of total foreigner population (NCSI, 2015). The total number of work force in the construction industry in Oman is approximately 700,000 (OSC, 2016; NCSI, 2015).

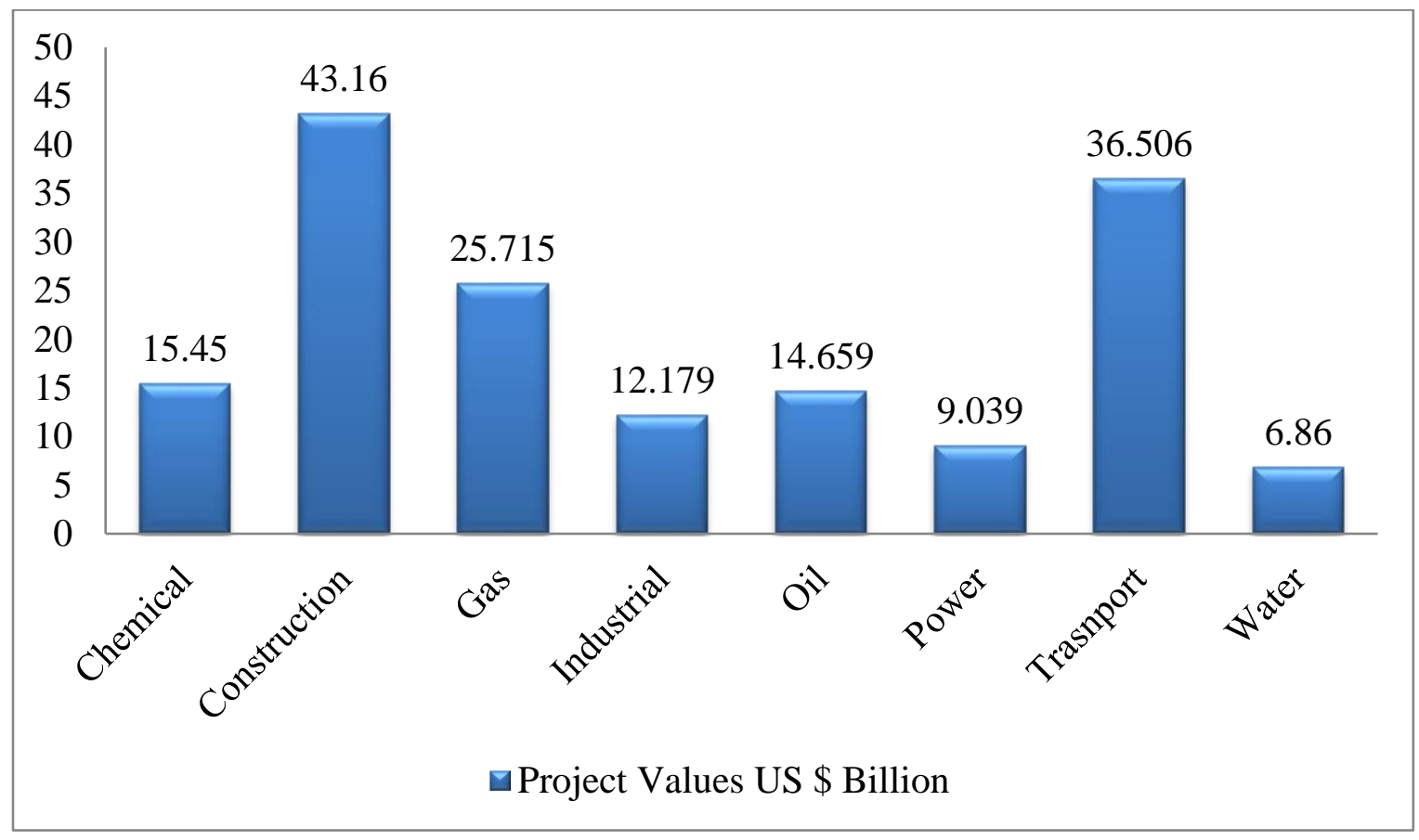


Figure 2. Values of Ongoing and Planned Projects in Different Sectors of Oman (Deloitte 2015)

In construction, delay could be defined as the time overrun either beyond completion date specified in a contract, or beyond the date that the parties agreed upon for delivery of a project. It is a project slipping over its planned schedule and is considered as common problem in construction projects. To the owner, delay means loss of revenue through lack of production facilities and rent-able space or a dependence on present facilities. In some cases, to the contractor, delay means higher overhead costs because of longer work period, higher material costs through inflation, and due to labor cost increases. Completing projects on time is an indicator of efficiency, but the construction process is subject to many variables and unpredictable factors, which result from many sources. These sources include the performance of parties, resources availability, environmental conditions, involvement of other parties, and contractual relations. However, it is rarely happen that a project is completed within the specified time. The main objectives of this study include the following:

- To review the publish literature and explore the main causes of delay in construction projects

- To identify the causes of delays in construction in Oman.

- To study the differences in perceptions of the three major parties in any constructions, namely, owners, contractors and consultants

\section{Literature Review:}

Construction projects are full of risk and uncertainties. Delays can have negative economic consequences and can create bad image for a contractor. One of the indicators for measuring the 
efficiency of a contractor is time. Clients who are mindful of the benefits they are likely to recoup from their investments would not want to have anything to do with contractors who cannot meet project completion deadlines. According to Gandhak and Sabihuddin (2014) delay is the late delivery of construction projects later than the time stipulated by parties to a contract. Delay was defined by Megha and Rajiv (2013) as the overrun of time beyond planned schedule. Project delays can result in loss of revenue to clients and high overhead cost to contractors because of time extension. Construction project risk can be countless and may emerge from different sources. The origin of risk may include performance of parties to the contract, conditions on site, contractual relations, availability of resources for regular progress of construction activities on site, and involvement of other parties. Delays in construction can be categorized into two, namely; excusable and non-excusable. They can be caused by clients, their agents, contractors or suppliers, or neither of the parties (Trauner et al 2009). Clients or their agents are the originators of excusable delays but non-excusable delays are caused by contractors (Tumi et al 2009). Construction delays can be termed excusable or non-excusable depending on the terms and conditions of a contract (Ochoa et al 2013, Trauner et al 2009, and Ahmed et al 2003). Contractors have no control over excusable delays. Where such delays occur, entitlement within the contract gives contractors the opportunity to seek for extension of time to complete the work (Trauner et al 2009). In addition to an extension of time, the contractor may also be entitled to recovery of cost related to the delay. In some instances the contractor would be entitled to both. Compensation of time extension or recovery of cost is given to the contractor because the occurrence of the delay may have been originated by the client or his agent (Mubarak 2005). On the other hand, non-excusable delays are foreseeable. They are events that the contractor has control over. The occurrence of such delays place limits on the contractor from 
asking for any extension of time or monetary compensation. Concurrent delay is however, an amalgamation of two or more isolated causes happening at the same time (Mubarak 2005). It can be defined as separate delays to the critical path that occur at the same time (Trauner et al 2009). This type of delay can be created by either the client or the contractor (Levy, 2006). Both parties to the contract assume responsibility for such delay and cannot retrieve damages.

Surveys conducted by Assaf et al. (1995) outlined 56 main causes of delay in large construction projects. Delay factors are assembled into nine major groups with different levels of importance to different parties. Al-Ghafly (1995) discussed the delay in public water and sewage projects. Sixty causes were identified and classified. Al-Ghafly (1995) concluded the following: the delay occurred frequently in medium and large size projects, and considered severe in small projects. There are many important causes of delay related to owner involvement, contractor performance, and the early planning and design of the project. Important causes are financial problems, changes in the design and scope, delay in making decisions and approvals by owner, difficulties in obtaining work permit, and coordination and communication problems. Chan and Kumaraswamy (1997) conducted a survey to evaluate the relative importance of 83 potential delay factors in Hong Kong construction projects and found five principal factors: poor risk management and supervision, unforeseen site conditions, slow decision making, client-initiated variations, and work variations.

Kaming et al. (1997) studied influencing factors on 31 high-rise projects in Indonesia and found out that cost overruns occur more frequently and are more severe problem than time overruns. They pointed out that the major factors influencing cost overrun are material cost increase due to 
inflation, inaccurate material estimation and degree of complexity. While in time overrun, the most important factors causing delays are design changes, poor labor productivity, inadequate planning, and resource shortages.

Kumaraswamy and Chan (1998) studied the causes of construction delays in Hong Kong. They found that there was a difference in perceptions as to causes of delays by different groups of participants in building and civil engineering works. They suggested that biases of different industry groups might direct blame for delays to other groups. Noulmanee et al. (1999) investigated causes of delays in highway construction in Thailand and concluded that delays can be caused by all parties involved in projects; however, main causes come from inadequacy of sub-contractors, organization that lacks of sufficient resources, incomplete and unclear drawings and deficiencies between consultants and contractors. The study suggested that delay can be minimized by discussions that lead to understanding.

Al-Momani (2000) investigated causes of delay in 130 public projects in Jordan. The main causes of delay were related to designer, user changes, weather, site conditions, late deliveries, economic conditions and increase in quantity. The study suggested that special attention to factors will help industry practitioners in minimizing contract disputes. Delays have strong relationship with failure and ineffective performance of contractors. The study conducted by Assaf and Sadiq (2006) summarized different causes of delay into nine groups of project, owner, contractor, consultant, design, material, equipment, labors, and external causes. The study reported the most frequent causes of delay according to owners, consultants and contractors as shown in table 1. 


\begin{tabular}{|c|c|c|c|}
\hline S.No. & Owners & Contractors & Consultants \\
\hline 1 & $\begin{array}{l}\text { Type of project bidding } \\
\text { and award }\end{array}$ & $\begin{array}{l}\text { Delay in progress payments } \\
\text { by owner }\end{array}$ & $\begin{array}{l}\text { Type of project bidding and } \\
\text { award }\end{array}$ \\
\hline 2 & Shortage of labors & $\begin{array}{l}\begin{array}{l}\text { Suspension of work by } \\
\text { owner }\end{array} \\
\end{array}$ & $\begin{array}{l}\text { Change orders by owner } \\
\text { during construction }\end{array}$ \\
\hline 3 & $\begin{array}{l}\text { Ineffective planning and } \\
\text { scheduling of project by } \\
\text { contractor }\end{array}$ & $\begin{array}{l}\text { Late in reviewing and } \\
\text { approving design documents } \\
\text { by owner }\end{array}$ & Shortage of labors \\
\hline 4 & $\begin{array}{l}\text { Low productivity level of } \\
\text { labors }\end{array}$ & $\begin{array}{l}\text { Change orders by owner } \\
\text { during construction }\end{array}$ & $\begin{array}{l}\text { Ineffective planning and } \\
\text { scheduling of } \\
\text { project by contractor }\end{array}$ \\
\hline 5 & Unqualified $\mathrm{v}$ & $\begin{array}{l}\begin{array}{l}\text { Late procurement of } \\
\text { materials }\end{array} \\
\end{array}$ & $\begin{array}{l}\text { Delay in progress payments } \\
\text { by owner }\end{array}$ \\
\hline 6 & $\begin{array}{l}\text { Change orders by owner } \\
\text { during } \\
\text { construction }\end{array}$ & $\begin{array}{l}\text { Mistakes and discrepancies } \\
\text { in design } \\
\text { documents }\end{array}$ & $\begin{array}{l}\text { Low productivity level of } \\
\text { labors }\end{array}$ \\
\hline 7 & $\begin{array}{l}\text { Hot weather effect on } \\
\text { construction activities }\end{array}$ & $\begin{array}{l}\text { Delays in producing design } \\
\text { documents }\end{array}$ & $\begin{array}{l}\text { Unavailability of incentives } \\
\text { for contractor to finish } \\
\text { ahead of schedule }\end{array}$ \\
\hline 8 & $\begin{array}{l}\text { Type of construction } \\
\text { contract }\end{array}$ & $\begin{array}{l}\text { Difficulties in financing } \\
\text { project by contractor }\end{array}$ & Ineffective delay penalties \\
\hline 9 & $\begin{array}{l}\text { Poor site management and } \\
\text { supervision by } \\
\text { contractor }\end{array}$ & $\begin{array}{l}\text { Late in reviewing and } \\
\text { approving design } \\
\text { documents by consultant }\end{array}$ & $\begin{array}{l}\text { Hot weather effect on } \\
\text { construction activities }\end{array}$ \\
\hline 10 & $\begin{array}{l}\text { Conflicts encountered with } \\
\text { subcontractors schedule in } \\
\text { project execution }\end{array}$ & $\begin{array}{l}\text { Slowness in decision-making } \\
\text { process by owner }\end{array}$ & $\begin{array}{l}\text { Poor qualification of the } \\
\text { contractors technical staff }\end{array}$ \\
\hline
\end{tabular}

Table 1. Delay causes by Owners, Contractors and Consultants (Assaf and Sadiq, 2006)

A recent study by Akomah and Jackson (2016) on the contractors' perception of factors contributing to road project delay reveals that delay in honoring payment certificates, bad weather conditions, unfavourable site conditions, consultant initiated variations, delay in instructions from consultants and difficulty in accessing bank credit are the most critical factors causing delay in road projects. The study also identified extension of time, cost overrun, damage to company's reputation, lost productivity and efficiency and rescheduling, claim and litigation 
as the major effects of road project delays. The study conducted by Adeyemi and Masalila (2016) identified 10 most important causes of delay from a list of twenty eight different causes and six different effects of delay. The ten most important causes are: contractor's improper planning, contractor's poor site management, inadequate contractor experience, inadequate client's finance and payments for completed work, problems with subcontractors, shortage in material, labor supply, equipment availability and failure, lack of communication between parties, and mistakes during the construction stage. The six main effects of delay were: time overrun cost overrun, disputes, arbitration, litigation and total abandonment.

\section{Research Aim and Methodology:}

The overall aim of this study is to evaluate the causes that contribute to delay the construction projects in Oman. In order to achieve this objective, a qualitative approach as opposed to a quantitative approach was taken in the study. Briefly, the distinction between these two research strategies is as follows. Quantitative research emphasises quantification in the collection and analysis of data. It takes a deductive approach to the relationship between theory and research and emphasis is placed on the testing of theories. Quantitative research incorporates the norms and practices of the natural scientific model and positivism. It views social reality as an external objective reality. A similar methodology was adopted by Tajeddini (2009) in his research on the perceptions of learning among Swiss watch managers. Tajeddini, and Trueman (2008) employed purposeful (judgmental) stratified sampling method in their research on the potential for innovativeness: a tale of the Swiss watch industry. The qualitative method of research was found more suitable by Tajeddini et al (2017) for the study of enterprising women in Bali. 
On the other hand, a qualitative research strategy puts emphasis on words and meanings rather than quantification in data collection. It emphasises an inductive approach in the relationship between theory and research and emphasis is placed on the generation of theories. Research can however combine both qualitative and qualitative approaches - a strategy increasingly referred to in the literature as mixed methods research (Bryman, 2012). Since the research reported in this paper is exploratory in nature, a qualitative enquiry was deemed to be the most appropriate approach to data collection. Semi-structured interviews were used to collect relevant information and the interview guide or set of questions used for the research are shown in the appendix. The interview process was flexible and the emphasis was on how the interviewees understood the different causes of delay in the projects handle by their organizations.

The interviewees were selected on a purposive sampling basis. Such sampling is strategic in nature and the philosophy or idea was to interview respondents who were relevant to the research questions. This was achieved by interviewing a total of six senior managers from leading construction contractors, owners and construction/ engineering consultants. Managers operating at a senior level in construction organizations, owners, and consultants of the construction projects were considered best placed to provide descriptions of the real world with respect to the main causes of delay. The objective of this work was to determine the main causes of delay in construction projects in Oman. The characteristics of the interviewees are presented here.

a) Interviewee one: A senior engineer in the ministry of transportation and communication in Oman having more than 20 years of project management experience in highway sector. The ministry of transportation and communication in Oman was initially established first time in 1973. 
b) Interviewee two: A senior project engineer in the ministry of housing in Oman with more than 25 years of experience of project management in building sector. The ministry of housing was initially established in 1972 as a planning department and was annexed to the ministry of development.

c) Interviewee three: A senior construction manager with over 10 years of experience in one of the major construction companies with offices in all GCC countries. The company is $100 \%$ privately owned with more than 1000 employees in Oman. The interviewee is currently working as project director of a highway construction project with an estimated cost of US \$ 305.90 million.

d) Interviewee four: A senior construction manager with over 12 years of experience in one of the main construction companies mostly work on the building projects. The Organization was established in the year 1992 and currently executing some of the main buildings projects pertaining to government and private sector in Oman. The construction manager interviewed from this organization is working on a construction project of an estimated cost of US \$ 60 million.

e) Interviewee five: A senior contract manager with over 15 years of experience in one of the world leading consulting organizations having offices in USA, Europe and Middle East. The organization was Founded in 1944, $100 \%$ owned by the employee stock ownership trust with a total revenues of $\$ 3.2$ billion in 2015 .

f) Interviewee six: A senior design consultant with more than 8 years of experience in one of the leading international consultants operating the Middle East, Africa, Asia, and Europe with more than 10,000 staff. The interviewee is currently involved as design and supervision consultant in some of the mega road projects in Oman. 
The use of semi-structured interviews in data collection offers the following strengths.

(a) It enables the researcher to examine the level of understanding that a respondent has about a particular topic - usually in slightly more depth than is possible with a postal questionnaire for example.

(b) It can be used as a powerful form of preliminary assessment. That is, it can be used to explore how a respondent feels about a particular topic before using a second method such as participant observation or in depth interviewing to gather greater depth of information. Semi-structured interviews can also be used to identify respondents whose views may be explored in more detail through the use of focus groups, for example.

(c) All respondents are asked most of the questions in the same way. This makes it easy to repeat or replicate the interview. In other words, this type of research method is easy to standardise.

(d) Provides a reliable source of data.

(e) The researcher can contact large numbers of people quickly, easily and efficiently.

The approach however suffers from a number of weaknesses and limitations including the following items.

(a) It can be time consuming if the sample group is very large. This is because the researcher or their representative needs to be present during the delivery of the semi-structured interview.

(b) The quality and usefulness of the information is highly dependent upon the quality of the questions asked.

(c) A substantial amount of pre-planning is required. 
(d) The format of questionnaire design makes it difficult for the researcher to examine complex issues and opinions. Even where open-ended questions are used, the depth of the answers that the respondent can provide tends to be more limited than with other qualitative methods.

(e) There is limited scope for the respondent to answer questions in any detail or depth.

Despite these limitations, the six respondents in this study provided a rich source of vital information which will be useful in further in-depth investigations on the subject.

In the next section, the results obtained through the interview process are assessed and evaluated.

\section{Analysis and Discussion of Results:}

\subsection{Contractual Issue:}

Successfully completion of construction projects on time requires clear information and understanding between different parties in the form of a contract agreement. Different types contract agreements and bidding procedure with inadequate definition may result disputes between different parties involved in construction project. Opinion was sought on the delay in construction projects caused by contractual issues.

Interviewee one and two argue that contract between different parties of a construction project is a legal document and need to be clearly understood in term of different aspect such as completion time and delay penalties. They noted that although this can cause the delay only if there is a major dispute which leads to the court legal proceedings. In such cases the work at project sometimes suspended till the matter is resolved by the court among the parties. They also emphasize on the effectiveness of the delay penalties as sometimes contractors believe that the duration of the project can be extended.

Interviewee four and six argues that the completion times especially in government sector project need to be set realistically. The contractors some time do not note the completion time even if it is shorter as they don't want to lose the contract. Eventually shorter contract duration will result to delay the project.

Interviewee five argues that change in specifications and post contract specifications needs additional understanding among the parties which can results to delay the work. 
All the interviewees agreed on the need of better understanding and compliance of contract agreement among different parties as this may result into dispute and can delay the construction project. They also emphasize on the different clauses to be clear enough to avoid any dispute and legal proceeding during the project.

\subsection{Workforce:}

Construction industry is highly populated by foreigner workers and constitutes $92 \%$ of the total workforce of construction in Oman. Hiring foreigner workers need administrative approval from several government organizations. Approximately the whole process needs a six month of duration.

All the interviewees agreed that most of the construction projects delayed because of the several issues of workforce such as availability, productivity, skills and management.

Interviewee one argues that most of the construction organizations start hiring of labor only after securing the award of contract. He emphasizes that there needs to be some physical check on the contractors during the prequalification process as they state their workforce. But actually they hire the staff after the award of contract which leads to delay the projects. He also stresses on the need proper check and balance on the capacity of construction organizations during the registration and renewal process.

Interviewee five and six noted that mostly construction organizations try to hire cheap workforce and compromise the skills and productivity which cause the delay of the projects.

Interviewee three and four highlighted several problems related to hiring workforce for their projects such as lengthy process of approval from different government organizations, ban on hiring several categories of occupation, and restriction on hiring local workforce.

\subsection{Materials:}

Although there was consensus among all the interviewee that the availability of construction materials on time is the key to maintain a proper progress of the work, but their view was considerably different.

Interviewee one and two noted that if the specifications for materials are clear in the contract document, then there will be no problem with the materials, but only in some special situation such as if there is a real shortage in the market. In Oman this kind of situation seldom happens.

Interviewee three and four argue that the selection and approval of special materials from both from owner and consultant take a longer time and mostly delay or suspend the work at 
construction project. They also emphasize that change in material types and specifications during construction project also cause the delay in completion. The non-availability and shortage of some materials in the local market also cause the delay.

\subsection{Payment:}

Different studies show that that delay of progress payment by the owner is one of the most severe causes of delay of construction projects. Delayed payments to contractors have knock-on effects on many activities of contractors, subcontractors and suppliers. On time payment processing and approval can help to continue the pace of work and maintain an effective progress. Most contractors argue that unnecessary delay in payment process results to a slow progress or suspension of work at the project. Opinion was sought on the delay in construction projects caused by payment issues.

Interviewee one stated the following on payment:

"The payment procedure should be clearly stated the in the contract document and all the parties needs to follow the instructions from the contract on the process of payment. This is the responsibility of contractors to submit their request to the owner through consultant with all required documents to process the payment. The consultant needs to verify the documents before it is submitted to the owner to process the payment. If consultant found any document missing, or there is a need for some clarifications or changes, then then payment document need to go back to the contractor for corrections. Most of the government sector follows the same procedure".

Interviewee two opinion was similar to interviewee one. He expressed that payment should not the cause delay to the project. The payment process needs to be agreed before the execution of the contract agreement and contractors should be provided with sufficient information on payment process so that there will be no conflict on this during the project period. The owner should honour the payment request upon receipt of completed document for payment from contractors through consultants.

Interviewee five and six shows a great concern on the delay of payment especially in government projects. They expressed that sometimes delay in payments results in suspension of works at a construction site. When payment to the contractor is delayed, most construction activities cannot be carried out and may stifle the contractor's cash flow.

Interviewee four pointed out that although the main contractors may have problems of late payment, however the main problem which actually causes the delay of construction project is the payment from main contractors to sub-contractors. In mega construction projects the main contractors normally split the works among sub-contractors. The subcontractors normally have 
less financial capacity and cannot maintain the progress of work without a speedy payment from the main contractor. This mostly results in delay of the project.

\subsection{Coordination between Construction Parties:}

Many researchers argue that a good coordination between project parties, i.e. owner, consultant and contractor is required for a smooth operation of different activities such as inspection, material approval, testing, and major changes in design or their approval.

All the interviewee agreed that a better coordination is require not only to avoid delay in construction projects, but also for successful completion of the project with all respects.

Interviewee three and four stated that one of the reasons in construction project delay is the delay is caused by lack of cooperation by consultant of the respective project. Interviewee four stated as under:

"In Oman, the contract agreement requires the inspection of completed work by consultant to continue the next step. For example if the subgrade is completed, the contractor is bound to wait for the consultant to do inspection first before they can start the sub base layer. This sometime take longer time than usual and we need to call the consulting staff several times. The same problem we face during the laboratory testing and approval. The main reason probably is for this is that the consultants have many projects and less field staff which affect the contractor work at site".

Interviewee three expresses a similar view and added that changes in design and their approval are sometimes also take longer time than usual which lead to delay the work at site. He also stated that government sector projects involved some special approval from higher authorities such as ornamental works and materials requires for this purpose. Contractors need to wait until such approvals are made in the government office which mostly caused the delay. Even sometimes the consultant engineers misunderstand the owner's requirements which result to change the design during the project. This somehow delays the execution of the project on time.

The view of all the remaining interviewee was almost similar. They feel that best coordination between all construction parties is very important for successful completion of project. However, in their view coordination is not something which caused significant delay to construction projects in Oman. 


\subsection{External Factors:}

Factors such as hot weather and rain etc. are some of the external factors which are not in the control of the project team i.e. owner, consultant and contractors but possibly can delay the project. Opinion was sought on the delay in construction projects caused by external factors.

All of the interviewee agreed and stated that external factors and different site condition caused delay to construction projects. Some of the external factors stated by the different interviewee which caused the delay to construction projects are;

- Effects of subsurface conditions (such as water table)

- Delay in obtaining permits from municipality

- Hot weather effect on construction activities

- Rain effect on construction activities

- Unavailability of utilities in site (such as, water, electricity)

- Traffic control and restriction at job site

- Accident during construction

Interviewee four stated external factors caused a significant delay to the construction projects and contractors face penalty even if delay is caused by such factors. External factors are beyond the control of the contractors and are not properly acknowledge by owner and consultant during accepting the request for extension in completion time of the projects.

\subsection{Other Causes of Delay in Oman:}

The causes of delay in construction may vary from project to project, but some of causes can be common even the project type ad nature may change. interviewee were asked to express their view on different factors which are more likely causing delay to construction projects of different nature in Oman. The perception of owner, consultant and contractor on main causes of delay in construction project is reported as under.

\section{Owner Perception:}

Both the interviewee from owner / client background expressed their view and stated the main causes of the delay in construction projects will sometime different from project to project, however some of them are very common in Oman which are as under:

- Project funding

- Workforce skills, productivity and shortage

- Poor planning and scheduling by contractor

- Different design consultant and supervision consultant 
- Bad weathering condition

- Delay from consultant in inspection and testing

- Change in scope of work

\section{Contractor Perception:}

Interviewee from contractor background highlighted that in most cases the contractor is held responsible for all the delay in construction projects which lead sometime to financial penalty and also legal proceedings. It is not necessary that the causes of delay of construction projects will be always link to the contractors. There is need to understand the causes of delay so that such causes can be avoided in future by effective strategies. They stated the following reasons for delaying the construction projects in Oman.

- Short duration of the project

- Delay in payment

- Material issues including shortage and approval

- Mistake and revision of design

- Workforce Issues

- Unnecessary interruption in site operation by owner and consultant

\section{Consultant Perception:}

Both the interviewee from consulting organizations stated that the responsibility of completion of construction projects on time lies on the contractors. Contractors need to manage the project in a way that they can effectively meet the target set by owners. At the same time the quality of the work should not be affected as well. This is also important for the reputation and good image of the construction organizations. The common causes of delay in construction projects in Oman stated by them are;

- Poor site management and supervision

- Ineffective planning and scheduling

- Unqualified workforce

- Low productivity of labour

- Conflict between contractor and owner

- Payment of sub-contractor by main contractor

- Frequent change of sub-contractors

- Late procurement of materials 


\section{Conclusion}

Causes of delay in construction project in Oman based on the results of a semi structured interviewed with owner, consultant and contractor are discussed. Delay caused by contractual issues, workforce, materials, coordination between construction parties, and external factors were the main item of the semi structure interview. The views of selected interviewee from owner; consultant and contractor background on these delay causes are discussed. The views of interviewee on some causes of delay are different, for example delay in payment is considered as one of the main cause of delay by contractor but the view of consultant and owner is significantly different. They don't consider payment as a major factor which causes the delay to construction projects in Oman. Similarly, there were consensus among the interviewee on some factors which cause the delay to construction project in Oman. For example external factors were considered as an important factor which causes the delay. They reported external factors by interviewee which causes the delay to construction projects in Oman are;

- Effects of subsurface conditions (such as water table)

- Delay in obtaining permits from municipality

- Hot weather effect on construction activities

- Rain effect on construction activities

- Unavailability of utilities in site (such as, water, electricity)

- Traffic control and restriction at job site

- Accident during construction

Owner, consultant and contractor are the important team player in successful completion of construction project. Any delay causing factor identified by any team player is important even if it is not considered as important by other party. The common delay causes identified by the interviewee are shown in figure 2. It is needed to be noted that causes of delay may vary from project to project as construction projects are mostly complex in nature and significantly different from each other. A good understanding of the various causes of delay will help construction project team to develop strategies to encounter such causes of delay and will help them to complete the project on time. On time completion of construction projects will turn a good reputation and image for both contractor and consultant, while the owner will be able to enjoy the benefits of the completed project. Delay in completion of construction project will result into suffering of all parties in different form. This research is exploratory in nature and provides basic causes of delay in construction project in general. Further research is recommended to explore project specific causes of delay in construction in Oman. 


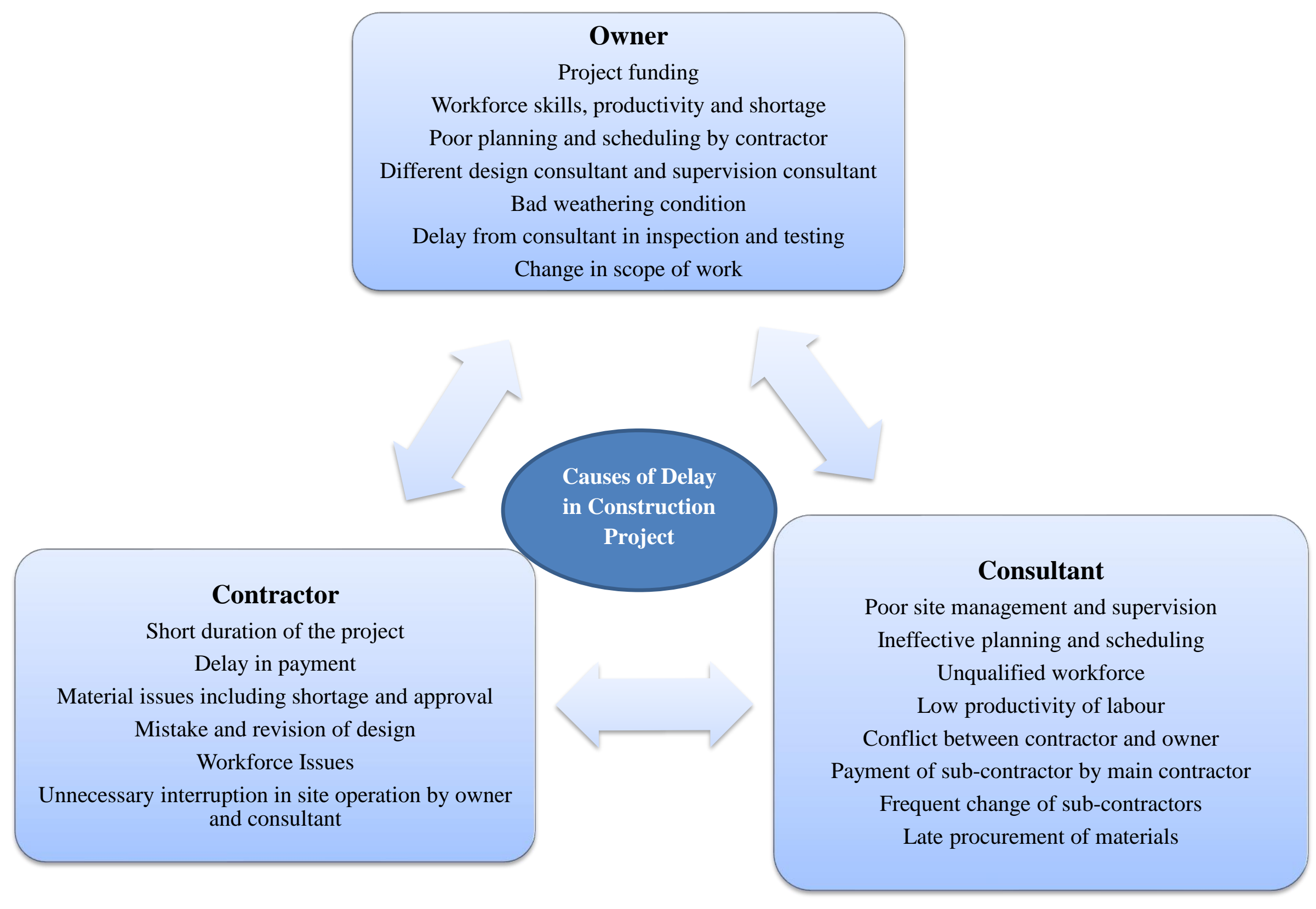

Figure 2. Causes of Delay in Construction Projects in Oman 


\section{Appendix:}

\section{Semi structures interview questions:}

1. Successfully completion of construction projects on time requires clear information and understanding between different parties in the form of a contract agreement. Different types contract agreements and bidding procedure with inadequate definition may result disputes between different parties involved in construction project. What is your view on the selection of different contract forms and bidding procedure? Are contractual issues can cause the delay to construction project?

2. Construction projects are mostly complex in the nature and have tight deadlines in terms of completion. Workforce availability, productivity and skills are some of the key requirement for on time completion of any project. Construction industry is highly populated by foreigner workers and constitutes $92 \%$ of the total workforce of construction in Oman. What is your view on the different causes of delay in construction projects which can be directly linked to workforce?

3. The availability of construction materials on time is the key to maintain a proper progress of the work. A speedy selection and approval of materials is require to complete the procurement process on time. What is your opinion on the delay in construction caused by materials?

4. On time payment process and approval can help to continue the pace of work and maintain an effective progress. Most contractors argue that unnecessary delay in payment process result to a slow progress or suspension of work at project. What is your opinion on the payment process and approval? Did you experienced delay in the construction projects due to payment delays?

5. Many researcher argues that a good coordination between projects parties i.e. owner, consultant and contractor is require for a smooth operation of different activities such as inspection, material approval, testing, and major changes in design or their approval. Do you think that these issues are among the major delay causes of construction projects in Oman?

6. Factors such as hot weather and rain etc. are some of the external factors which are not in the control of the project team i.e. owner, consultant and contractors but possibly can delay the project. Base on your experience, how much such external factors contributes to the delay of the construction projects in Oman. Apart from environment factors, are there any other factors which can be classified as external factors and can delay the construction? 
7. The causes of delay in construction may vary from project to project, but some of causes can be common even the project type ad nature may change. Based on your experience, what are the main causes of delay in construction projects in Oman?

\section{References:}

Aderemi Y. Adeyemi, Keabetswe Masalila (2016). Delay Factors and Time-Cost Performance of Construction Projects in Gaborone City Council, Botswana. Journal for the Advancement of Performance Information \& Value 8(01): 01-18

Ahmed, S. M., Azhar, S., Kappagntula, P., Gollapudil, D., 2003, Delays in construction: A brief study of the Florida construction industry. In proceedings of 39th Annual ASC Conference, Clemson, South Carolina (Charles W. Berryman (eds)). pp. 257-66. Clemson University, USA

Al-Ghafly MA. 1995. Delays in the construction of public utility projects in Saudi Arabia. Master thesis, CEM Dept., KFUPM, Dhahran, Saudi Arabia.

Al-Momani AH. 2000. Construction delay: a quantitative analysis. International Journal of Project Management; 18(1):51-9.

Assaf SA, Al-Khalil M, Al-Hazmi M. 1995. Causes of delays in large building construction projects. ASCE Journal of Management Engineering; 11(2): 45-50.

Benjamin Boahene Akomah and Emmanuel Nana Jackson (2016). Contractors' Perception of Factors Contributing to Road Project Delay. International Journal of Construction Engineering and Management, 5(3): 79-85

Bryman A (2012) Social Research Methods, 4th edn. Oxford University Press, Oxford, UK. Chan DW, Kumaraswamy MM. 1997. A comparative study of causes of time overruns in Hong Kong construction projects. Int J Project Manage;15(1):55-63.

Deloitte (2015), Deloitte GCC Powers of Construction 2015 Construction - The economic barometer for the region. See https://businesshumanrights.org/sites/default/files/documents/Deloitte-GCC-Powers-of-Construction-2015.pdf (accessed 15/10/2016).

Gandhak, P. S., and Sabihuddin, S., 2014, Stakeholders' perception of the causes and effect of construction delays on project delivery, International Journal of Modern Engineering Research (IJMER), 14(2), 153-161.

GLMN (2015), Gulf Labour Markets and Migration report No. 9/2015 Issued by Gulf Research Centre. See http://gulfmigration.eu/media/pubs/exno/GLMM_EN_2015_09.pdf (accessed 15/10/2016). 
Kaming P, Olomolaiye P, Holt G, Harris F. 1997. Factors influencing construction time and cost overruns on high-rise projects in Indonesia. Construction Management and Economics;15(1): 83-94.

Kumaraswamy M, Chan D. 1998. Contributors to construction delay. Construction Management and Economics; 16(1):17-29.

Levy, S. M., 2006, "Project Management in Construction”, McGraw-Hill, USA.

Megha, D., and Rajiv, B., 2013, A methodology for ranking of causes of delay for residential construction projects in Indian context, International Journal of Emerging Technology and Advanced Engineering, 3(3), 396-404.

Mubarak, S., 2005, “Construction Project Scheduling and Control” Pearson Prentice Hall, USA.

NCSI (2015) National Center for Statistics and Information, Oman. Statistical Year Book 2015, Issued No. 43. See

https://www.ncsi.gov.om/Elibrary/LibraryContentDoc/ben_Statistical_Year_Book_2015_740d0 da1-01d2-4f42-a159-6102a49ecf59.pdf (accessed 15/10/2016).

Noulmanee A, Wachirathamrojn J, Tantichattanont P, Sittivijan P. Internal causes of delays in highway construction projects in Thailand. www.ait.c1et.com, July, 1999.

Ochoa, G., Melchor-Aguilar, D., Mondié, S., 2013, Critical parameters of integral delay systems, International Journal of Robust and Nonlinear Control, 25(7), 1094-1105.

OSC, 2016. Oman Society of Contractor, annual general meeting report, 2016. See http://www.osc.org.om/downloads.html accessed (15/10/2016).

Sadi A. Assaf and Sadiq Al-Hejji (2006). Causes of delay in large construction projects. International Journal of Project Management, 24(4): 349-357

Tajeddini, K., 2009. Perceptions of learning among Swiss watch managers. Journal of Workplace Learning, 21(7), pp.525-537.

Tajeddini, K. and Trueman, M., 2008. The potential for innovativeness: a tale of the Swiss watch industry. Journal of Marketing Management, 24(1-2), pp.169-184.

Tajeddini, K., Walle, A.H. and Denisa, M., 2017. Enterprising Women, Tourism, and Development: The Case of Bali. International Journal of Hospitality \& Tourism Administration, 18(2), pp.195-218. 
Trauner, J. T., Manginelli, W. A., Lowe, J. S., Nagata, M. F., Furniss, B. J., 2009, Construction delays, 2nd Edition, Understanding them clearly and delay analysis in construction analyzing them correctly, Elsevier Inc, London.

Tumi, S. A. H., Omran, A. and Pakir, A. H. K., 2009, Causes of delay in construction industry in Libya. In proceedings of the International Conference Administration and Business. Faculty of Administration and Business, University of Bucharest, Romania. pp. 265-272. 